\title{
Viscumins functionally modulate cell motility-associated gene expression
}

\author{
SONJA SCHÖTTERL ${ }^{1}$, MIRIAM HÜBNER ${ }^{1}$, ANGELA ARMENTO ${ }^{1}$, VIVIEN VENINGA ${ }^{1}$, NAITA MAREN WIRSIK ${ }^{2}$, \\ SIMON BERNATZ ${ }^{2}$, HANS LENTZEN ${ }^{3}$, MICHEL MITTELBRONN ${ }^{2}$ and ULRIKE NAUMANN ${ }^{1}$ \\ ${ }^{1}$ Molecular Neuro-Oncology, Hertie Institute for Clinical Brain Research and Center Neurology, \\ University of Tübingen, D-72076 Tübingen; ${ }^{2}$ Edinger Institute (Neurological Institute), Goethe University, \\ D-60528 Frankfurt/Main; ${ }^{3}$ Melema Pharma GmbH, D-20148 Hamburg, Germany
}

Received October 21, 2016; Accepted December 19, 2016

DOI: $10.3892 /$ ijo.2017.3838

\begin{abstract}
In Europe extracts from Viscum album L., the European white-berry mistletoe, are widely used as a complementary cancer therapy. Viscumins (mistletoe lectins, ML) have been scrutinized as important active components of mistletoe and exhibit a variety of anticancer effects such as stimulation of the immune system, induction of cytotoxicity, reduction of tumor cell motility as well as changes in the expression of genes associated with cancer development and progression. By microarray expression analysis, quantitative RT-PCR and RT-PCR based validation of microarray data we demonstrate for the Viscum album extract Iscador $\mathrm{Qu}$ and for the lectins Aviscumine and ML-1 that in glioma cells these drugs differentially modulate the expression of genes involved in the regulation of cell migration and invasion, including processes modulating cell architecture and cell adhesion. A variety of differentially expressed genes in ML treated cells are associated with the transforming growth factor (TGF)- $\beta$ signaling pathway or are targets of TGF- $\beta$. ML treatment downregulated the expression of TGF- $\beta$ itself, of the TGF- $\beta$ receptor II (TGFBR2), of the TGF- $\beta$ intracellular signal transducer protein SMAD2, and of matrix-metalloproteinases (MMP) MMP-2 and MMP-14. Even if the changes in gene expression differ between Aviscumine, Iscador Qu and ML-1, the overall regulation of motility associated gene expression by all drugs showed functional effects since tumor cell motility was reduced in a ML-dependent manner. Therefore, ML containing compounds might provide clinical benefit as adjuvant therapeutics in the treatment of patients with invasively growing tumors such as glioblastomas.
\end{abstract}

Correspondence to: Dr Ulrike Naumann, Molecular NeuroOncology, Hertie Institute for Clinical Brain Research and Center Neurology, University of Tübingen, Otfried-Müller-Strasse 27, D-72076 Tübingen, Germany

E-mail: ulrike.naumann@uni-tuebingen.de

Key words: glioma, viscumins, cell motility, TGF- $\beta$, gene expression

\section{Introduction}

Glioblastoma (GBM) is the most aggressive primary brain tumor in adults. The overall survival, even at best therapy and standard care, is normally less than 15 months, also long-term survival is rare (1). Surgical resection followed by irradiation and chemotherapy using temozolomide is currently still the standard treatment for patients with GBM. However, despite novel therapy approaches, the outcome remains poor. GBM are characterized by a diffuse and infiltrative growth into the surrounding healthy brain parenchyma (2). Even if GBM does not metastasize outside the brain, the expression of many proteins involved in metastatic processes like MMPs that destroy the extracellular matrix (ECM), cell adhesion molecules (CAM) such as integrins, cadherins or selectins that are necessary for cell-cell or cell-ECM interactions, members of the TGF- $\beta$ signaling cascade which regulates cell migration and proteins involved in cell metabolism or transcription factors involved in the epithelial to mesenchymal transition (EMT) are dysregulated in GBM cells (3-8).

Today, Viscum album extracts are known under several trade names, such as Iscador, AbnobaVISCUM, Helixor and others which are mainly available in European countries. Dependent on the host tree the mistletoe is growing on, the time the plant is harvested as well as on the technique how the drug is prepared, the compounds in different Viscum album extracts vary. Important compounds of mistletoe extracts providing anticancer effects are ML-1, ML-2, ML-3 and viscotoxins (VT). VT are small peptides inducing cytotoxicity whereas MLs are glycosylated type II ribosomal inhibitory proteins (RIP II) of two subunits of which the $\alpha$-chain serves as a toxic $28 \mathrm{~S}$ rRNA N-glycosidase. Other ingredients of Viscum album extracts with known effects on mammalian cells are oligo- and polysaccharides as well as flavonoids and triterpenes. ML-1 is known to be an important anticancer compound within the MLs $(9,10)$.

We and others have shown that in cancer cells ML containing drugs not only block protein translation as predicted by the ML function such as RIPs, but also provide multimodal anticancer functions. At higher concentration these drugs induce cytotoxicity in cancer cells, potentiate cellular anticancer immune responses, alter the expression of cancer associated genes and 
reduce tumor growth in mice (11-15). Until today it is not completely understood how these plant extracts transmit their function as regulators of gene expression. Are VTs or other minor compounds like triterpenoids or flavonoids present in the extracts, beside the MLs, involved in the observed alteration in gene expression? Do MLs have to be glycosylated to be efficiently taken up by tumor cells and to transmit their function? To determine whether different ML containing drugs alter the expression of genes involved in cancer progression such as metastasis/motility associated genes and if the glycosylation of MLs, or minor additional compounds present in some preparations, are involved in gene regulation, we used three different ML containing drugs: Iscador $\mathrm{Qu}$, a Viscum album extract, Aviscumine, a recombinant ML-1 and purified ML-1 from mistletoe plants growing on ash trees. We could demonstrate that these three drugs, even to a different level, modulate gene expression of motility associated genes and reduce glioma cell motility in a ML-dependent way.

\section{Materials and methods}

Mistletoe preparations. Iscador Qu, kindly provided by Iscador AG (Lörrach, Germany), is a fermented extract prepared from the mistletoe growing on oaks. It contains high amounts of MLs as well as VTs and other minor compounds such as oligo- and polysaccharides, triterpenes, flavonoids and others. $\mathrm{ML}$ and VT contents were as follows: Iscador $\mathrm{Qu}_{20}$ (Charge 4080/3: total ML $1095 \mathrm{ng} / \mathrm{ml}$ as determined by the provider using an ELISA assay detecting ML1-3, VT $48 \mu \mathrm{g} / \mathrm{ml}$ ). Aviscumine (ME-503), a recombinant, but non-glycosylated ML-1 produced in E. coli (16) and purified to GMP quality, was a kind gift of Hans Lentzen (Melema Pharma $\mathrm{GmbH}$, Hamburg Germany). Purified glycosylated ML-1 isolated from mistletoes growing on ash trees was a kind gift of Christoph Heyder (Abnoba GmbH, Pforzheim, Germany) (17-21).

Cell culture. LNT-229 human malignant glioma cells, kindly provided by Nicolas de Tribolet (Lausanne, Switzerland), were maintained in Dulbecco's modified Eagle's medium (DMEM; Gibco-Life Technologies, Eggenstein, Germany) containing $10 \%$ fetal calf serum (FCS; Gibco), penicillin $(100 \mathrm{U} / \mathrm{ml})$, streptomycin $(100 \mu \mathrm{g} / \mathrm{ml})$ in a humidified atmosphere containing $5 \% \mathrm{CO}_{2}$. Cell viability was measured using crystal violet staining as previously described (15).

Microarray analysis and quantitative RT-PCR. For microarray analysis RNA of treated and untreated cells was isolated using the RNApure isolation kit (Macherey-Nagel GmbH, Düren, Germany) and transcribed into cDNA using SuperScript II (Invitrogen, Karlsruhe, Germany). For each sample $10 \mu \mathrm{g}$ reverse transcribed total RNA in a volume of $1080 \mu \mathrm{l}$ in DNasefree water was mixed with $1080 \mu \mathrm{l}$ TaqMan Gene Expression Master Mix (Thermo Fisher Scientific, Waltham, MA, USA), dispensed in $20 \mu \mathrm{l} /$ well into the TaqMan Array Human Tumor Metastasis 96-well plate (cat. no. 4414098; Thermo Fisher Scientfic) and run on an ABI 7500 system.

For quantitative reverse transcribed polymerase chain reaction (RT-qPCR) cDNA was prepared as for the microarray analysis. Quantitative PCR was determined using SYBRGreen Master Mix (Thermo Fisher Scientific) on a Roche
LightCycler 480. Relative mRNA expression was quantified ([E $\mathrm{E}^{\Delta \mathrm{CT}}$ (gene of interest)/ $\mathrm{E}^{\Delta \mathrm{CT}}$ (housekeeping gene)]). The following primers were used: EPHB2 forward, 5'-CCACTCAT CATCGGCTCCTC-3' andEPHB2 reverse, 5'-GCTCAAACCC CCGTCTGTTA-3'; GAPDH forward, 5'-TGCACCACCAA CTGCTTAGC-3' and GAPDH reverse, 5'-GGCATGGACTG TGGTCATGAG-3'; IL1B forward, 5'-GCTCGCCAGTGA AATGATGG-3' and IL1B reverse, 5'-GGTGGTCGGAGATT CGTAGC-3'; MMP-2 forward, 5'-CCAGAGACAGTGGAT GATGCC-3' and MMP-2 reverse, 5'-GGAGTCCGTCCTTA CCGTCAA-3'; MMP-14 forward, 5'-CGGCCCTTTCCAG CCTCTG-3' and MMP-14 reverse, 5'-GAGGTCTGAGGGTC CTGCC-3'; MTA1 forward, 5'-CCCAGTAGGGGTCTGGCA AA-3' and MTA1 reverse, 5'-GGTAGGACTTCCCGTTGA GC-3'; NME forward, 5'-AGCCGGAGTTCAAACCTAA GC-3' and NME reverse, 5'-TTTGTGTGTCTGCCTCCC CT-3'; PTGS2 forward, 5'-GTTCCACCCGCAGTACAGAA-3' and PTGS2 reverse, 5'-AGGGCTTCAGCATAAAGCGT-3'; SERPINB5 forward, 5'-CATCCAGGTCTTTGTGCTCCT-3' and SERPINB5 reverse, 5'-GGGCCTGGAGTCACAGTTA TC-3'; TGFB1 forward, 5'-GCCCTGGACACCAACTAT TG-3' and TGFB1 reverse, 5'-CGTGTCCAGGCTCCAAA TG-3'; TGFB2 forward, 5'-CAAAAGCCAGAGTGCCTG AA-3' and TGFB2 reverse, 5'-CAGTTACATCGAAGGAGA GC-3'; TGFBR2 forward, 5'-GGAGTTTCCTGTTTCCCCC G-3' and TGFBR2 reverse, 5'-AGGGAAGCTGCACAGGA GTC-3'; TIMP-2 forward, 5'-GTTTATCTACACGGCCCC CT-3' and TIMP-2 reverse, 5'-TCGGCCTTTCCTGCAAT GAG-3'. RT-qPCR cycling conditions were $95^{\circ} \mathrm{C}$ for $10 \mathrm{~min}$, followed by 45 cycles at $95^{\circ} \mathrm{C}$ for $15 \mathrm{sec}, 60^{\circ} \mathrm{C}$ for $1 \mathrm{~min}$ and $72^{\circ} \mathrm{C}$ for $20 \mathrm{sec}$.

Immunoblot analysis. The general procedure has been previously described (22). Supernatants were generated by cultivating cells in serum deprived medium for $48 \mathrm{~h}$, followed by a centrifugation step to avoid contamination. Protein contents were analyzed according to Bradford (BCA; Thermo Fisher Scientific). Following antibodies were used: anti-MMP-2 (Merck Millipore, Darmstadt, Germany), anti-MMP-14 (Epitomics, Burlingame, CA, USA), anti-GAPDH (Santa Cruz Biotechnology, Dallas, TX, USA), anti-Smad2/3 (Cell Signaling Technology, Danvers, MA, USA) and anti-TIMP-2 (R\&D Systems GmbH, Wiesbaden, Germany). Protein contents were quantified using the ChemiDoc MP system and ImageLab software (Bio-Rad Laboratories $\mathrm{GmbH}$, Munich, Germany).

Immunofluorescence. LNT-229 cells $\left(1 \times 10^{5}\right)$ were seeded on poly-L-lysin coated glass coverslips in 12-well plates and treated after attachment for different time-points with $8 \mathrm{ng} / \mathrm{ml}$ of ML Iscador Qu, Aviscumine, ML-1 or were left untreated. The cells were fixed in $4 \%$ paraformaldehyde for $10 \mathrm{~min}$, washed three times with phosphate-buffered saline (PBS) and blocked in $10 \%$ goat serum with $0.3 \%$ Triton X-100 in PBS for $1 \mathrm{~h}$ followed by overnight incubation with $2 \mu \mathrm{g} / \mathrm{ml}$ anti-ML antibody or isotype rabbit IgG (Santa Cruz Biotechnology) at $4^{\circ} \mathrm{C}$. The polyclonal rabbit anti-ML antibody was a kind gift of the Iscador AG. To visualize the bound antibody the cells were stained with a goat anti-rabbit Alexa Fluor 488 antibody (Thermo Fisher Scientific) for $1 \mathrm{~h}$, mounted with Vectashield HardSet Mounting medium with DAPI (Vector Laboratories 
Table I. ML preparations used in the present study.

\begin{tabular}{llll}
\hline Preparation & Manufacturer & Host tree & \\
\hline Iscador Qu & Iscador AG & Oak & $\begin{array}{l}\text { Fermented extract, high ML-content, contains glycosylated MLs, } \\
\text { and minor compounds such as viscotoxins, flavonoids and } \\
\text { triterpenes, oligo- and polysaccharides }\end{array}$ \\
Aviscumine & Melema Pharma GmbH & - & $\begin{array}{l}\text { Recombinant, unglycosylated ML-1 produced in E. coli } \\
\text { ML-1 }\end{array}$ \\
Abnoba AG & Ash & Purified ML-1, glycosylated protein
\end{tabular}

Inc., Burlingame, CA, USA) and examined by confocal microscopy using a Zeiss LSM 510. Images were analyzed with the software ImageJ.

TGF- $\beta$ ELISA. LNT-229 cells were seeded and treated with Iscador Qu, Aviscumine, ML-1 (8 $\mathrm{ng} / \mathrm{ml}$ of $\mathrm{ML}$ ) for $24 \mathrm{~h}$ or were left untreated. To block the effect of the ML treatment, the polyclonal rabbit anti-ML antibody $(4.8 \mu \mathrm{g} / \mathrm{ml})$ was added to ML containing medium 30 min before adding the drugs to LNT-229 cells. After addition of MLs, cell supernatants were generated and concentrated using $4 \mathrm{kDa}$ Amicon centrifugal filters (Merck Millipore). Protein concentrations for normalization were determined using the Bradford array. The ELISA was performed according to instruction of the manufacturer (RayBiotech, Norcross, GA, USA).

Boyden chamber migration assay. LNT-229 cells were seeded in 12-well plates, were allowed to attach and treated with Iscador Qu, Aviscumine, ML-1 (8 ng/ml ML) or were left untreated. To block the effect of ML, a pan-specific polyclonal rabbit anti-ML antibody (Iscador AG) neutralizing the effects of ML-1, -2 and -3 was added 30 min prior to the addition of ML containing drugs to glioma cells. After $24 \mathrm{~h}$ of ML treatment, the cells were washed to remove residual ML and $2 \times 10^{4}$ cells were seeded in doublets in membrane inserts of transwell migration chambers $(8 \mu \mathrm{m}$ pores; Corning Incorp., Corning, NY, USA). Migrated cells were fixed $24 \mathrm{~h}$ later with methanol, stained with hematoxylin and counted as previously described (15). To avoid errors in the quantification of cell migration derived from differences in cell proliferation between ML treated and untreated cells, in parallel $1 \times 10^{4}$ of the cells were seeded in triplets in microwell plates, stained with crystal violet as described $24 \mathrm{~h}$ later (22) and were used for normalization of cell migration.

Statistical analysis. If not mentioned otherwise, the figures show the mean or one representative experiment out of at least three independent experiments as indicated. Quantitative data were assessed for significance by unpaired Student's t-test $(\mathrm{P}<0.05 ; \mathrm{P}<0.01 ; \mathrm{P}<0.001)$.

\section{Results}

Different effects of Iscador Qu, Aviscumine and $M L-1$ on the expression of cell motility associated genes in LNT-229 glioma cells. In our previous experiments we have observed that ML-rich Iscador Qu, but not ML-poor Iscador P, reduces the expression of genes involved in tumor development and progression such as genes regulating proliferation, cell survival or immune surveillance. Genes found to be upregulated in glioma were mainly downregulated by Iscador $\mathrm{Qu}$ whereas genes found to be downregulated in GBM specimen were upregulated (15 and data not shown). To analyze the influence of different ML preparations on the expression of motility associated genes and to evaluate whether the glycosylation of MLs influences gene expression, we used three different ML containing drugs (Table I). To avoid cytotoxicityrelated changes in gene expression we first determined the $\mathrm{EC}_{50}$ values $(24 \mathrm{~h})$ for all preparations in LNT-229 cells and found them to be $37 \mathrm{ng} / \mathrm{ml}$ of ML (Iscador Qu), $95 \mathrm{ng} / \mathrm{ml}$ (Aviscumine) and $>240 \mathrm{ng} / \mathrm{ml}$ (ML-1). For further experiments we used ML concentrations that were far below $\mathrm{EC}_{50}$ values (up to $8 \mathrm{ng} / \mathrm{ml} \mathrm{ML}$ for Iscador Qu, up to $8 \mathrm{ng} / \mathrm{ml}$ Aviscumine and up to $16 \mathrm{ng} / \mathrm{ml} \mathrm{ML-1)}$. To analyze differences in gene expression induced by the three preparations we treated LNT-229 glioma cells for $24 \mathrm{~h}$ with $8 \mathrm{ng} / \mathrm{ml}$ of ML (Iscador Qu). This concentration induces $<15 \%$ of cell number reduction in LNT-229 (15). A concentration of $8 \mathrm{ng} / \mathrm{ml}$ of $\mathrm{ML}$ in Iscador Qu counts for $0.35 \mu \mathrm{g} / \mathrm{ml}$ of $\mathrm{VT}$, a concentration at which we have never observed cytotoxicity if treating glioma cells with a comparable VT concentration present in ML poor Iscador $\mathrm{P}$ (15). For Aviscumine or ML-1, we used concentrations up to $16 \mathrm{ng} / \mathrm{ml} \mathrm{ML}$, which is also far below the determined $\mathrm{EC}_{50}$ value. All concentrations used in the experiments are below those that are necessary to kill non-tumor brain cells (15 and data not shown).

Using a PCR based microarray measuring the expression of 92 metastasis associated genes, quantitative RT-PCR of well-known genes involved in the regulation of cell motility, as well as RT-PCR based validation of differentially expressed genes identified by the microarray analysis, we identified 33 cell motility/invasion modulating genes that were regulated by at least one ML containing drug in LNT-229 glioma cells. The levels of 18 mRNAs decreased, whereas the levels of 15 mRNAs rose upon treatment. For Iscador Qu, 15 mRNAs were downregulated and 7 upregulated. For Aviscumine, 8 mRNAs were downregulated and 14 upregulated. For ML-1, 8 mRNAs were downregulated and 10 upregulated suggesting that minor compounds present in the mistletoe extract Iscador $\mathrm{Qu}$ might enhance downregulation of mRNA expression (Fig. 1 and Table I). Besides this, we detected differences in mRNA expression after the treatment of LNT-229 cells with either non-glycosylated Aviscumine or glycosylated ML-1, especially in the group of upregulated mRNAs (Fig. 1). In the 
A

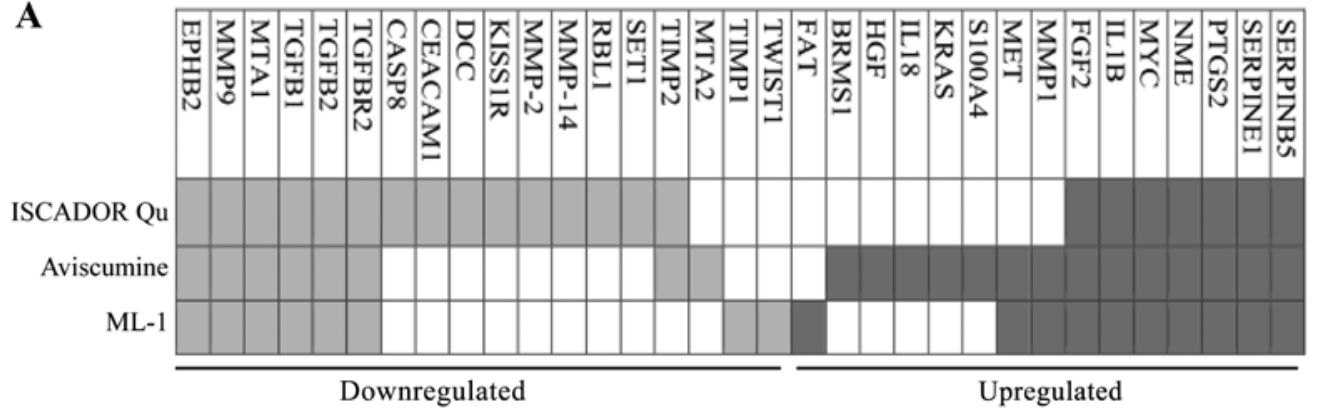

B

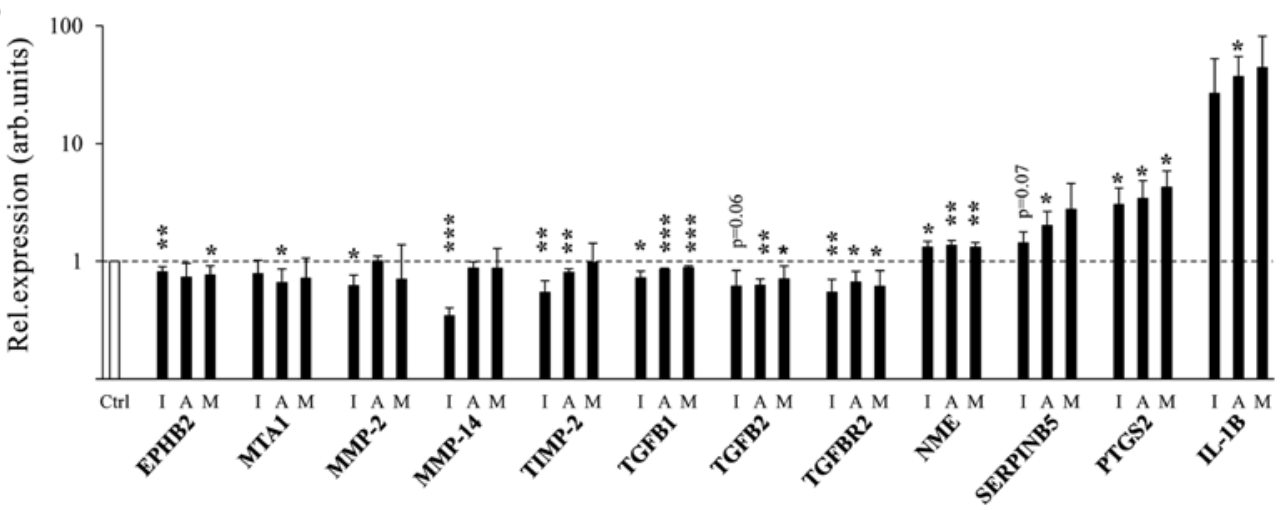

Figure 1. ML containing drugs induce changes in the expression of motility associated genes. (A) Heat map depicting gene expression changes in LNT-229 glioma cells treated for $24 \mathrm{~h}$ with Iscador Qu, Aviscumine or ML-1 at a concentration of $8 \mathrm{ng} / \mathrm{ml}$ of ML. (B) Modified expression of 12 genes (EPHB2, MTA1, MMP-2, MMP-14, TIMP-2, TGFB1, TGFB2, TGFBR2, NME, SERPINB5, PTGS2 and IL1B) determined by microarray data was validated in ML treated cells $(8 \mathrm{ng} / \mathrm{ml}, 24 \mathrm{~h})$ cells in comparison to untreated cells by RT-qPCR, using GAPDH as reference gene $\left(\mathrm{n}=3, \mathrm{SD},{ }^{*} \mathrm{P}<0.05 ;{ }^{* * *} \mathrm{P}<0.01 ;{ }^{* * *} \mathrm{P}<0.001\right.$, significance level compared to control treated cells). I, Iscador Qu; A, Aviscumine; M, ML-1.
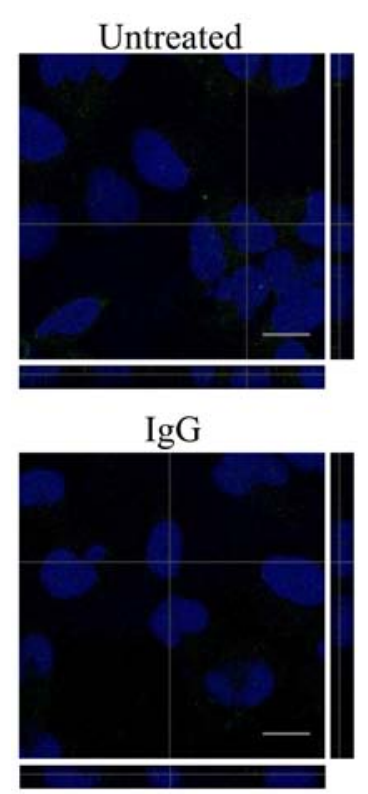
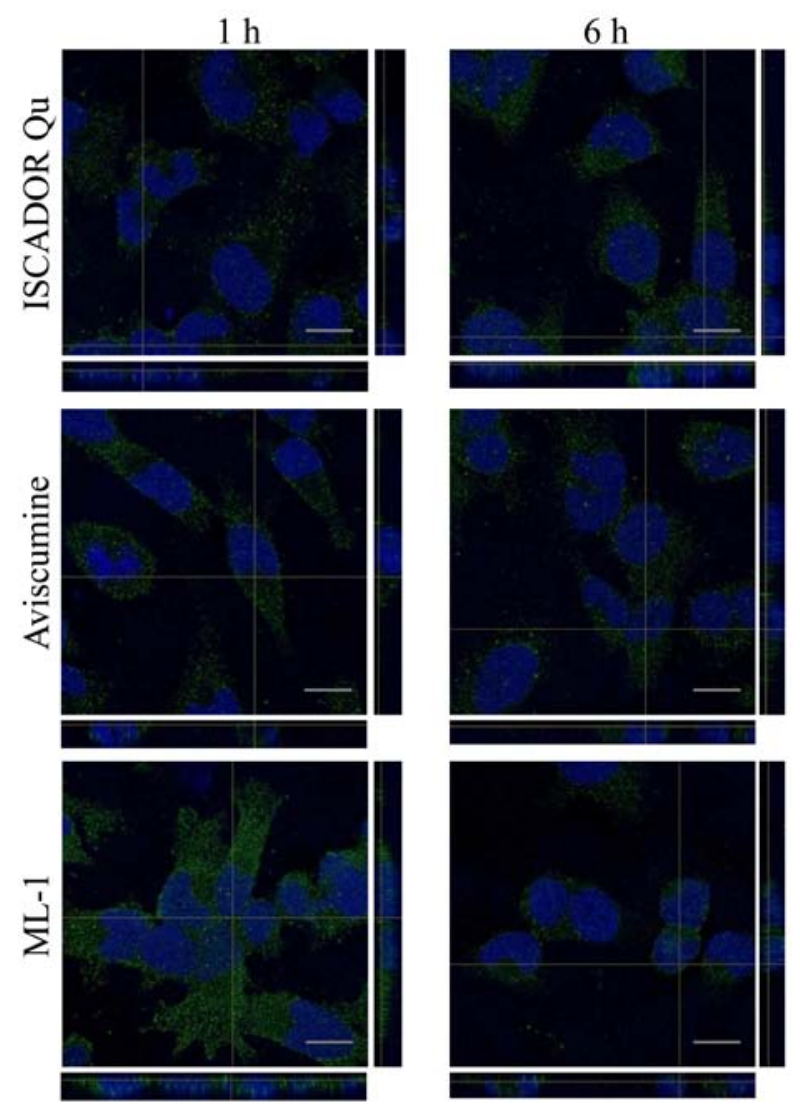

Figure 2. MLs were taken up by glioma cells. Z-stack confocal images of LNT-229 cells after 1 and 6 h of treatment with 8 ng/ml of ML. ML was stained with a pan-ML-specific antibody (green) and nuclei were stained with DAPI (blue) at 40-fold magnification. YZ (right) and XZ (bottom) views next to each picture demonstrate cytoplasmic localization of ML. As a control the cells were treated for $1 \mathrm{~h}$ with $8 \mathrm{ng} / \mathrm{ml} \mathrm{ML}-1$ followed by incubation with isotype IgG, scale bars depict $15 \mu \mathrm{m}$. Pictures represent one of three independent experiments. 

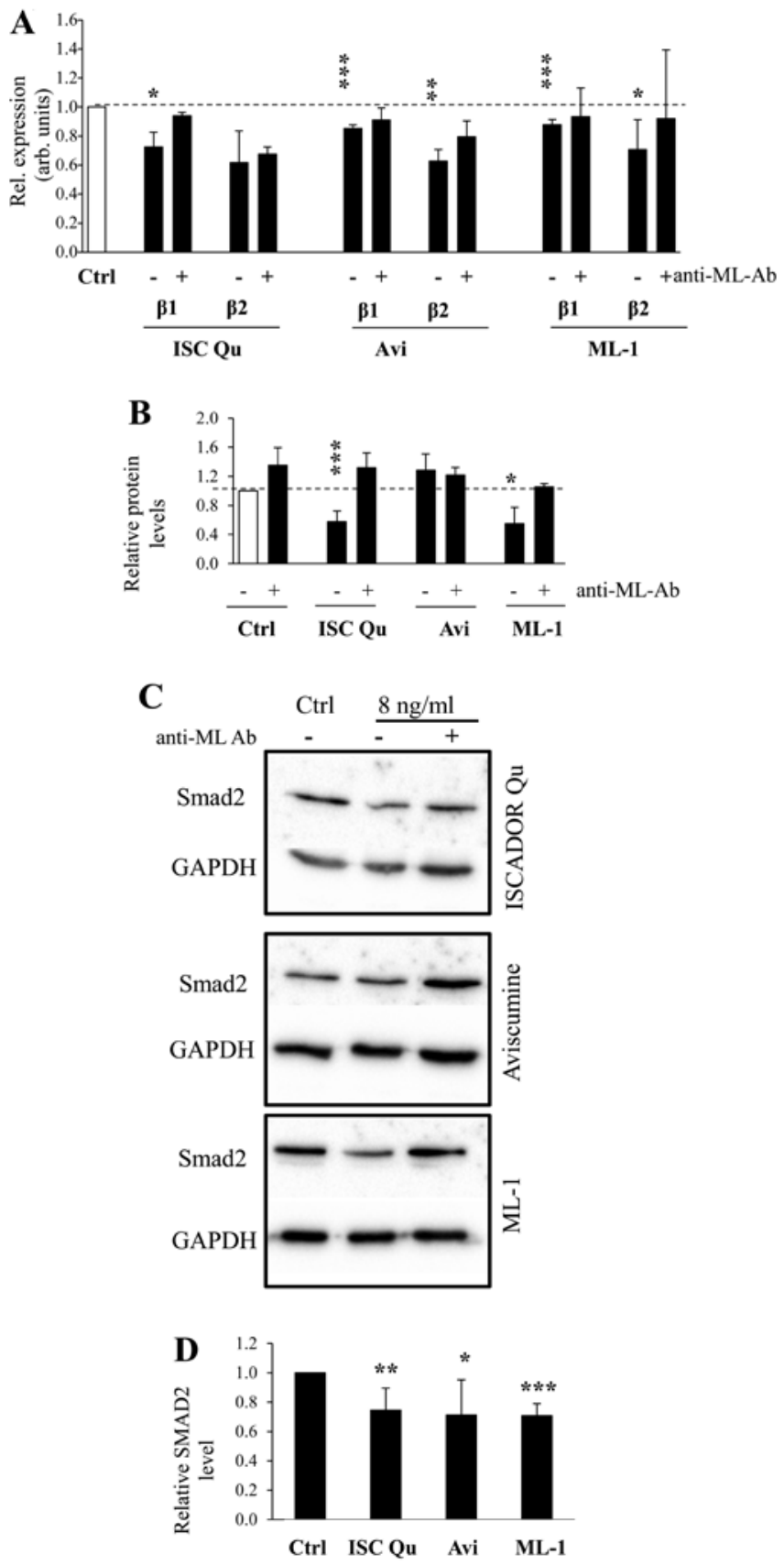

Figure 3. ML containing drugs modulate the expression of TGF- $\beta$ and its intracellular transducer SMAD2. (A) Downregulated expression of TGF- $\beta 1$ and TGF- $\beta 2$ in Iscador Qu, Aviscumine or ML-1 treated LNT-229 cells $(8 \mathrm{ng} / \mathrm{ml}$ $\mathrm{ML}, 24 \mathrm{~h}$ ) in comparison to untreated cells by RT-qPCR, using GAPDH as reference. Coincubation of ML drugs with a ML-neutralizing antibody $(4.8 \mu \mathrm{g} / \mathrm{ml}, 30 \mathrm{~min})$ was used to block ML specific effects. (B) Protein levels of TGF- $\beta 1$ in LNT-229 supernatants were quantified by ELISA. The cells were treated as in A, and afterwards cultivated in serum-free medium for $48 \mathrm{~h}$ to generate supernatants. (C) SMAD2 protein expression in ML treated LNT-229 cells. The cells were treated as in A and protein analysis was done by immunoblot, one of three independent experiments is shown. (D) Quantification of SMAD2 protein was prepared from three independent experiments. (A/B/D $\mathrm{n}=3, \mathrm{SD},{ }^{*} \mathrm{P}<0.05 ;{ }^{* * *} \mathrm{P}<0.01 ;{ }^{* * *} \mathrm{P}<0.001$, significance level compared to control treated cells).

group of the 18 downregulated mRNAs, 16 mRNAs code for genes harboring pro-migratory or pro-invasive function, the function of two genes (RBL1 and KISS1R) is controversially discussed. In the group of 15 upregulated mRNAs, 4 mRNAs are known to provide anti-motility effects (BRMS1, FGF2, NME and SERPINB5), 7 are described to be pro-migratory (FAT1, IL-18, KRAS, MMP1, PTGS2, S100A4 and SERPIN1) and 4 mRNAs provide either pro- or anti-migratory effects dependent on the micro-milieu in which they are expressed (HGF, IL-1B, MET and MYC) (Fig. 1).

Differential expression of motility associated genes is independent from variations in the lectin uptake by glioma cells. To analyze whether the differences in gene expression induced by Iscador Qu, Aviscumine or ML-1 might be caused by differences in the uptake of MLs present in these drugs and might also depend on the glycosylation of MLs, this influencing the uptake, we treated the cells with a concentration that counts for a subtoxic concentration of $8 \mathrm{ng} / \mathrm{ml}$ of ML and performed immunofluorescence experiments using a panspecific ML antibody. As demonstrated in Fig. 2, MLs from all three preparations were incorporated by the cells $1 \mathrm{~h}$ after treatment. At this time-point, the intensity of ML staining was approximately equal for Iscador Qu and Aviscumine, whereas ML-1 uptake was enhanced. At a later time-point (6 h), MLs were taken up equally independent of their glycosylation or from additional compounds being present in Iscador $\mathrm{Qu}$.

$M L$ containing drugs influence the expression of proteins involved in the TGF- $\beta$ signaling pathway in glioma cells. TGF- $\beta$ is one of the most important tumor promoting cytokines in GBM since in glioma cells TGF- $\beta$ provides immunosuppressive function and induces a more migratory phenotype (23). We have demonstrated previously that TGF- $\beta$ was downregulated by Iscador Qu (15). We now demonstrate that both TGF- $\beta 1$ and $-\beta 2$ mRNAs were also downregulated by Aviscumine and ML-1, and co-incubation of the preparations with a ML-specific antibody prior to the treatment of glioma cells reversed this effect (Fig. 3A). In addition to TGF- $\beta$, also TGF- $\beta$ receptor type II (TGFBR 2 ) mRNA is reduced (Fig. 1B). The downregulation of TGF- $\beta$ mRNA in ML treated LNT-229 glioma cells also leads to a downregulation of the TGF- $\beta 1$ protein by at least Iscador Qu and ML-1 (Fig. 3B). Notably, even if SMAD2, a prominent intracellular transducer protein of the TGF- $\beta$ signaling, was not modulated on its mRNA level (data not shown), SMAD2 protein is reduced in ML treated glioma cells ML-dependently (Fig. 3C and D) suggesting that this effect might be induced by the function of MLs as RIPs.

Matrix metalloproteinases are major players in the destruction of the ECM, a process necessary for invasive tumor cell growth. It is well known that TGF- $\beta$ modulates the expression and activity of MMPs and also of MMP inhibitors and activators in invasive cancer cells and also in gliomas $(3,24)$. We have also shown in a recent publication that Iscador $\mathrm{Qu}$ downregulates MMP expression (15). By microarray, qPCR and immunoblot analyses we now demonstrate that this, but to a different extent, is also true for the other ML containing drugs. In LNT-229 cells, the treatment with Iscador Qu significantly reduced the expression of MMP-2, of the tissue inhibitor of metalloproteinase (TIMP)-2 and of MT-1MMP/ MMP-14 mRNA at a concentration of $8 \mathrm{ng} / \mathrm{ml}$ of ML, whereas this effect was minor for ML-1 and not detectable for Aviscumine. For MMP-14, a significant downregulation 
A

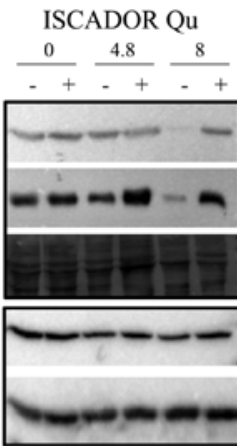

B

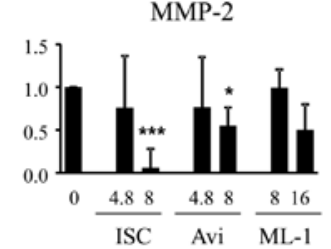

Aviscumine

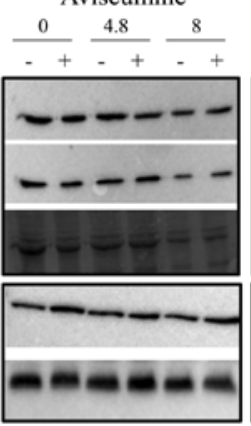

ML-1

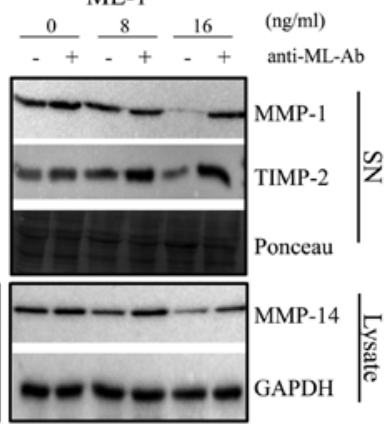

MMP-14
TIMP-2
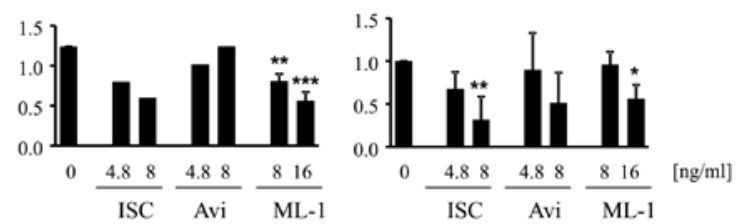

Figure 4. Iscador Qu, Aviscumine and ML-1 reduce MMP-2, MT1-MMP/MMP-14 and TIMP-2 expression. (A) LNT-229 cells were treated with increasing concentrations of Iscador Qu (ISC), Aviscumine (Avi) or ML-1. Coincubation of ML containing drugs with a ML neutralizing antibody (4.8 $\mu \mathrm{g} / \mathrm{ml}, 30 \mathrm{~min}$ ) prior to treatment was used to block ML specific effects. Supernatants and protein lysates were prepared as described in Materials and methods. (B) Quantification of MMP-14, MMP-2 and TIMP-2 protein levels from three independent experiments. For normalization of specific protein contents in supernatants, ponceau S stained lanes were used, in lysates GAPDH serves as housekeeping gene $(n=3, \mathrm{SD})$.

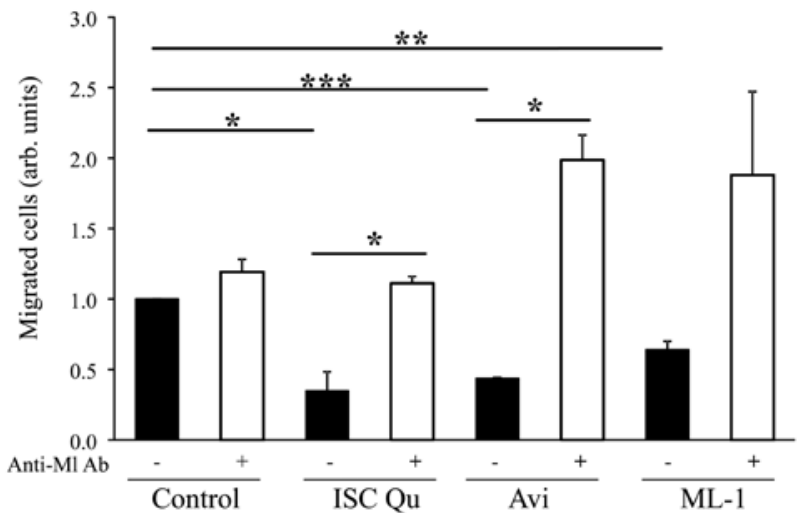

Figure 5. Iscador Qu, Aviscumine and ML-1 mitigate the migration of LNT-229 cells. LNT-229 cells were treated with Iscador Qu (ISC), Aviscumine (Avi), ML-1 (8 ng/ml ML, 24 h) or left untreated (control). A pan-specific ML antibody $(4.8 \mu \mathrm{g} / \mathrm{ml})$ was used to reverse the effect of the ML treatment as described before. For migration, 20,000 treated cells were seeded in Transwell migration chambers. After $24 \mathrm{~h}$ migrated cells were fixed, stained with haematoxylin and counted. $\left(\mathrm{n}=3, \mathrm{SD},{ }^{*} \mathrm{P}<0.05 ;{ }^{* *} \mathrm{P}<0.01 ;{ }^{* * *} \mathrm{P}<0.001\right)$.

of MMP-14 mRNA was observed exclusively in Iscador Qu treated cells whereas TIMP-2 mRNA was reduced by both Iscador Qu and Aviscumine (Fig. 1B). Notably, the differences in MMP-2, MMP-14 and TIMP-2 mRNA downregulation by the different preparations are not directly translated into protein levels. Whereas Iscador Qu downregulates MMP-2 and TIMP-2 at a concentration of $8 \mathrm{ng} / \mathrm{ml}$ of ML in glioma cell supernatants, at this ML concentration lesser effects were detectable for Aviscumine and not detectable for ML-1. MT1-MMP/MMP-14, that converts inactive pro-MMP-2 into its active form, was slightly reduced by Iscador Qu and ML-1, but not by Aviscumine at $8 \mathrm{ng} / \mathrm{ml}$. A concentration of $16 \mathrm{ng} /$ $\mathrm{ml}$ of ML-1 has to be used to achieve the same effect as determined for Iscador Qu. In contrast to changes in the mRNA expression observed by ML treatment, the downregulation in MMP and TIMP protein levels was dependent on the presence of MLs since addition of a ML-specific antibody reversed the observed effect almost completely (Fig. 4).

Iscador Qu, Aviscumine and ML-1 reduce glioma cell migration. Since a variety of genes associated with glioma cell invasion and migration are differentially regulated by ML treatment and even by different ML containing drugs, we analyzed whether the regulation of motility associated gene expression induced by ML functionally affects glioma cell motility. As demonstrated by Podlech et al (15) for Iscador Qu and now validated for Iscador $\mathrm{Qu}$, but also shown for Aviscumine and ML-1, ML containing drugs significantly reduce glioma cell migration. The reduction of cell migration is dependent on the presence of MLs since addition of a ML-binding antibody completely abrogates the migration inhibitory effect (Fig. 5).

\section{Discussion}

Until today no effective therapy regimens are available for malignant GBM. One important characteristic issue for the treatment failure in glioma is its highly invasive growth that makes a complete resection impossible. A therapeutic drug that inhibits GBM cell motility, does not provide severe side-effects and that can be used as an adjuvant during radiation and chemotherapy might therefore further improve the prognosis of GBM patients. Viscum album extracts or ML-1 containing drugs show, at least in vitro and in cancer mouse models, therapeutic impact such as induction of cell death, inhibition of tumor cell proliferation and stimulation of the anticancer immune response (21,25-31). Besides this, several clinical trials have demonstrated benefits of this therapy for cancer patients such as enhancement of the quality of life, lesser side-effects of chemotherapy and, for certain cancer entities, 
also slower tumor growth and a prolongation of survival $(9,32$ 35). We have previously shown that Iscador $\mathrm{Qu}, \mathrm{a} \mathrm{ML}$ rich extract, also mitigates the motility of glioma cells (15). The focus of this project was to identify motility associated genes regulated by ML containing drugs to determine if different preparations provide comparable effects in gene regulation and whether changes in motility associated gene expression by ML containing drugs also lead to the inhibition of glioma cell motility.

Working concentrations of the different ML preparations were chosen for three reasons: i) Since no further information was available about the concentration of ML-1 in Iscador Qu, we chose a concentration that counts for maximal $8 \mathrm{ng} / \mathrm{ml}$ of total ML and a non-toxic concentration of $0.35 \mathrm{ng} / \mathrm{ml} \mathrm{VT}$. These concentrations do not induce cell death or caspase activity in LNT-229 cells and provide $<15 \%$ reduction in cell growth (15). ii) There is a direct comparison possible regarding the effects of Aviscumine and ML-1 since these agents only differ in their gylcosylation status: ML-1 being naturally glycosylated and Aviscumine not. iii) Due to the lower toxic effect of ML-1 $\left(\mathrm{EC}_{50}>240 \mathrm{ng} / \mathrm{ml}\right)$ higher concentrations of ML-1 might be used during cancer therapy. For this we also tested the effect of $16 \mathrm{ng} / \mathrm{ml}$ of ML-1 on gene expression in glioma cells. On the level of reduced expression in treated glioma cells, all tested ML containing drugs downregulate the pro-migratory genes ephrin B2 (EPHB2), metastasis-associated protein 1 (MTA1), TGFBR2, its ligands TGF- $\beta 1$ and $-\beta 2$ and the TGF- $\beta$ intracellular transducer protein SMAD2, however to different levels (Figs. 1 and 3). TGF- $\beta$ is one of the most important pro-tumorigenic cytokines in glioma. Besides its immunosuppressive function, it enhances glioma cell invasion and migration via triggering the activation of MMPs and therefore, destruction of the ECM $(3,23)$. SMAD2 is a central transducer protein in the TGF- $\beta$ signaling cascade and its activity is regulated by phosphorylation (36). However, if the ML-induced reduction of TGF- $\beta$ alone is sufficient for the reduction of the intracellular TGF- $\beta$ signaling and the downregulation of TGF- $\beta$ target genes, or if the downregulation of TGFBR2 and SMAD2 further enhances these effects, remains unclear. Overexpression of the TGF- $\beta$ target EPHB2 in glioma cells reduces cell adhesion and induces cell migration and invasion in vivo and in vitro, whereas silencing of EPHB2 decreases tumor cell migration and is connected to the proto-oncogene Ras $(37,38)$, which we have also found to be downregulated by Iscador Qu and ML-1. MTA1, also a target of TGF- $\beta$, has been described to promote motility and invasiveness of pancreas carcinoma cells and is amplified in highly invasively growing cells developed from recurrent GBM (39). Whether the downregulation of EPHB2 mRNA or other TGF- $\beta$ target genes like MMP-2 is a direct effect of MLs or whether it is mediated by reducing the intracellular TGF- $\beta$ signal has not been examined so far. Iscador Qu, that besides MLs, also contains VTs and minor ingredients such as triterpenes, flavonoids and others, provides superior effects in mRNA downregulation compared to Aviscumine and ML-1. In Iscador Qu treated glioma cells, 15 mRNAs were downregulated, whereas only 8 mRNAs were downregulated by Aviscumine or ML-1, respectively. The differences in the mRNA regulatory effects do not seem to be dependent on the uptake of MLs since after $6 \mathrm{~h}$, intracellular ML was equally detectable for Iscador $\mathrm{Qu}$, Aviscumine and
ML-1 (Fig. 2). Even if mRNA downregulation was dependent on at least ML-1 present in all preparations as demonstrated by the addition of the ML-specific antibody (Figs. 3 and 4), the glycosylation of ML-1 does not seem to be important for its inhibitory function since nearly the same profile of downregulated genes were identified in Aviscumine and ML-1 treated glioma cells (Fig. 1). The superior effects of Iscador Qu are potentially caused by additional compounds in this extract. It has been recently published that triterpenes as well as flavonoids provide antitumor activity, can influence mRNA expression involving the expression, secretion and activation of MMP-2, a mRNA we solely found to be significantly downregulated in Iscador Qu treated LNT-229 cells (Fig. 1) $(40,41)$. In the panel of mRNAs that were only downregulated by Iscador Qu we found genes with prominent pro-migratory function. In glioma cells, a reduction of caspase-8 (CASP8) below basal levels results in a reduction of cell migration (42), CEACAM1 is an adhesion molecule that promotes migration and invasion of several cancers $(43,44)$ and the netrin-1 receptor DCC promotes filopodia formation and cell spreading by activating CDC42 and Rac1 (45). The TGF- $\beta$ responsive genes MMP-2, MMP-14 and TIMP-2, the latter also serving as an activator for MMP-2, are important proteins of glioma cell motility (46) and the nuclear proto-oncogene SET1 stimulates cell migration in a Rac1-dependent manner, its knockdown inhibits cell migration and invasion of breast cancer cells (47). The function of the KISS1 receptor (KISS1R) and the retinoblastoma like protein (RBL1) are controversially discussed. KISS1R can enhance tumor cell spreading but has been also described to stimulate invadopodia formation and cancer cell invasion (48). In GBM and metastatic colon cancer cells, RBL1/p107 showed enhanced expression compared to normal tissue, but its level falls during invasion (49).

In the group of 15 upregulated mRNAs, 4 mRNAs are known to provide anti-motility or anti-invasive function (BRMS1, FGF2, NME and SERPINB5), 7 are described to be pro-migratory (FAT1, IL-18, KRAS, MMP1, PTGS2, S100A4 and SERPIN1) and 4 mRNAs provide either pro- or anti-migratory effects dependent on the circumstances under which they are expressed in tumor cells (HGF, IL1B, MET and MYC; Table II). In the panel of upregulated anti-migratory/anti-invasive mRNAs, the breast-cancer metastasis suppressor 1 (BRMS1) has been described to suppress glioma progression by regulating invasion, migration and adhesion (50). Higher expression of fibroblast growth factor 2 (FGF2) was observed in the lesser invasive proneural GBM subtype compared to invasively growing mesenchymal subtype GBMs. Besides this, GBM patients with a lower expression of the FGF2-dependent PDGF receptor A (PDGFRA) have a better prognosis than patients with high amounts of PDGFRA $(51,52)$. Nucleoside diphosphate kinase A (NME) has been suggested to play an important role in the suppression of glioma invasion and migration $(53,54)$ and the serpin peptidase inhibitor, member 5 (SERPIN5B/ MASPIN) which is often silenced in GBM by promoter hypermethylation, effectively suppresses migration and invasiveness of malignant cancer cells $(55,56)$. However, some genes upregulated by mistletoe treatment harbor promigratory or pro-invasive function, but this does not lead to functional consequences (Fig. 5). Even if the expression of 


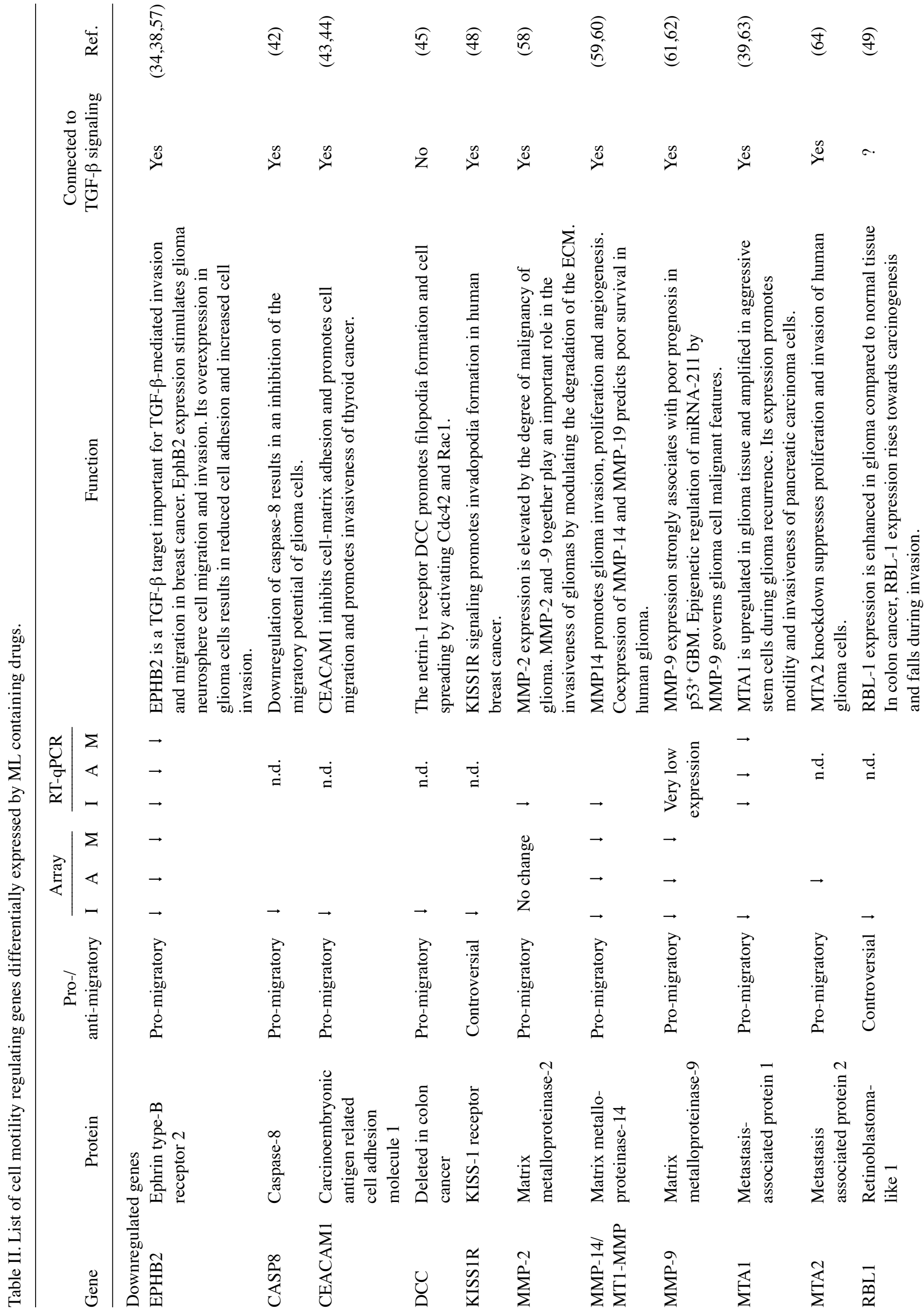




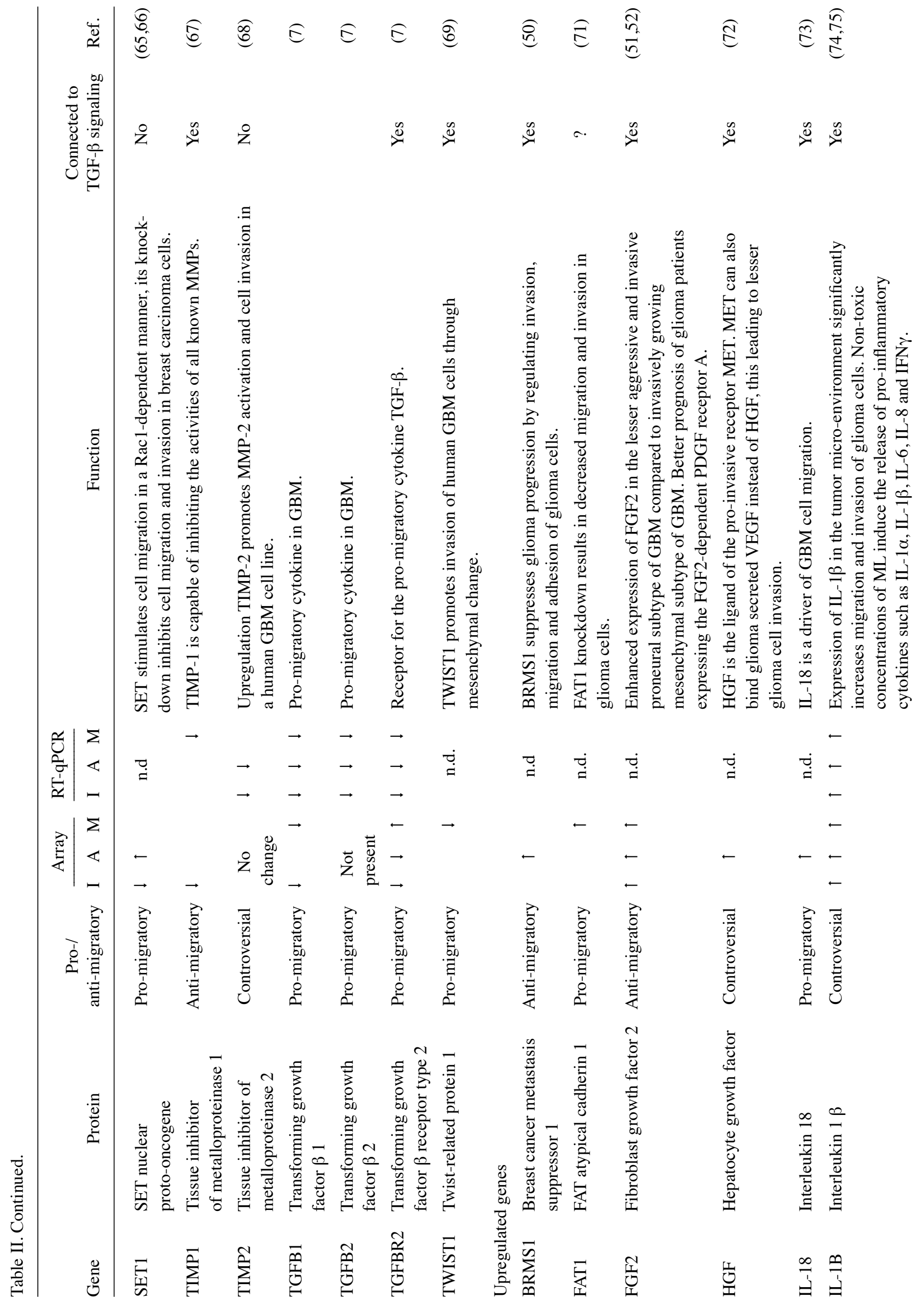




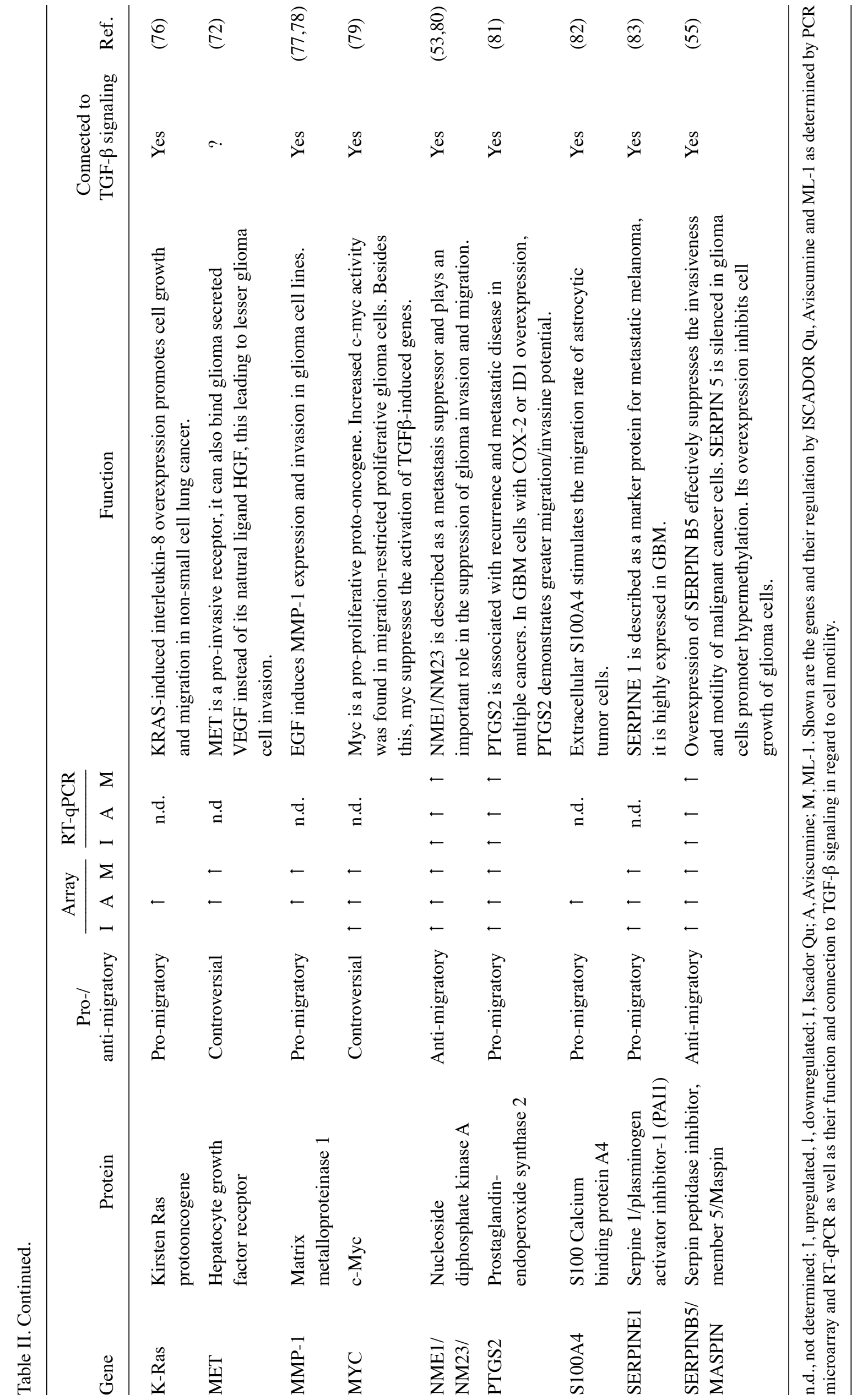


genes involved in metastatic, pro-migratory or pro-invasive processes differs between the three ML preparations we tested, the anti-migratory effect of all substances was nearly equal. This might be a result not only by changes in gene expression induced by MLs, but also an effect transmitted by the function of MLs as inhibitors of ribosomal translation, or a secondary effect by modulating the transcription or translation of certain transcription or transcriptional cofactors. Nevertheless, ML containing compounds like Iscador $\mathrm{Qu}$, Aviscumine or even ML-1 might provide clinical benefit as adjuvant therapeutics in the treatment of patients with invasively growing tumors.

\section{Acknowledgements}

The authors would like to thank the ISUS Foundation, the Software AG Foundation and Iscador AG for funding of the present study. They also thank the Iscador AG, Melema Pharma $\mathrm{GmbH}$ and Abnoba $\mathrm{GmbH}$ for providing us with the appropriate material.

\section{References}

1. Stupp R, Mason WP, van den Bent MJ, Weller M, Fisher B, Taphoorn MJ, Belanger K, Brandes AA, Marosi C, Bogdahn U, et al; European Organisation for Research and Treatment of Cancer Brain Tumor and Radiotherapy Groups; National Cancer Institute of Canada Clinical Trials Group: Radiotherapy plus concomitant and adjuvant temozolomide for glioblastoma. $\mathrm{N}$ Engl J Med 352: 987-996, 2005.

2. Claes A, Idema AJ and Wesseling P: Diffuse glioma growth: A guerilla war. Acta Neuropathol 114: 443-458, 2007.

3. Wick W, Platten M and Weller M: Glioma cell invasion: Regulation of metalloproteinase activity by TGF-beta. J Neurooncol 53: 177-185, 2001.

4. Wild-Bode C, Weller M and Wick W: Molecular determinants of glioma cell migration and invasion. J Neurosurg 94: 978-984, 2001.

5. Wick W, Naumann U and Weller M: Transforming growth factorbeta: A molecular target for the future therapy of glioblastoma. Curr Pharm Des 12: 341-349, 2006.

6. Kahlert UD, Nikkhah G and Maciaczyk J: Epithelial-tomesenchymal(-like) transition as a relevant molecular event in malignant gliomas. Cancer Lett 331: 131-138, 2013.

7. Naumann U, Harter PN, Rubel J, Ilina E, Blank AE, Esteban H and Mittelbronn M: Glioma cell migration and invasion as potential target for novel treatment strategies. Transl Neurosci 4: 314-329, 2013.

8. Kathagen A, Schulte A, Balcke G, Phillips HS, Martens T, Matschke J, Günther HS, Soriano R, Modrusan Z, Sandmann T, et al: Hypoxia and oxygenation induce a metabolic switch between pentose phosphate pathway and glycolysis in glioma stem-like cells. Acta Neuropathol 126: 763-780, 2013.

9. Mistletoe Extracts: $\left(\mathrm{PDQ}^{\circledR}\right)$ : Health Professional Version. In: PDQ Cancer Information Summaries (Internet), Bethesda (MD), 2016. Available from: https://www.ncbi.nlm.nih.gov/books/ NBK66054/.

10. Yau T, Dan X, Ng CC and Ng TB: Lectins with potential for anti-cancer therapy. Molecules 20: 3791-3810, 2015.

11. Elluru S, Duong Van Huyen JP, Delignat S, Prost F, Bayry J, Kazatchkine MD and Kaveri SV: Molecular mechanisms underlying the immunomodulatory effects of mistletoe (Viscum album L.) extracts Iscador. Arzneimittelforschung 56 (6A): 461-466, 2006.

12. Büssing A and Schietzel M: Apoptosis-inducing properties of Viscum album L. extracts from different host trees, correlate with their content of toxic mistletoe lectins. Anticancer Res 19 (1A): 23-28, 1999.

13. Pryme IF, Bardocz S, Pusztai A and Ewen SW: Suppression of growth of tumour cell lines in vitro and tumours in vivo by mistletoe lectins. Histol Histopathol 21: 285-299, 2006.
14. Hajtó T, Fodor K, Perjési P and Németh P: Difficulties and perspectives of immunomodulatory therapy with mistletoe lectins and standardized mistletoe extracts in evidence-based medicine. Evid Based Complement Alternat Med 2011: 298972, 2011.

15. Podlech O, Harter PN, Mittelbronn M, Pöschel S and Naumann U: Fermented mistletoe extract as a multimodal antitumoral agent in gliomas. Evid Based Complement Alternat Med 2012: 501796, 2012.

16. Schöffski P, Riggert S, Fumoleau P, Campone M, Bolte O, Marreaud S, Lacombe D, Baron B, Herold M, Zwierzina H, et al; European Organization for Research and Treatment of Cancer New Drug Development Group: Phase I trial of intravenous aviscumine (rViscumin) in patients with solid tumors: A study of the European Organization for Research and Treatment of Cancer New Drug Development Group. Ann Oncol 15: 1816-1824, 2004.

17. Urech K, Schaller G and Jäggy C: Viscotoxins, mistletoe lectins and their isoforms in mistletoe (Viscum album L.) extracts Iscador. Arzneimittelforschung 56 (6A): 428-434, 2006.

18. Jung ML, Baudino S, Ribéreau-Gayon G and Beck JP: Characterization of cytotoxic proteins from mistletoe (Viscum album L.). Cancer Lett 51: 103-108, 1990.

19. Eck J, Langer M, Möckel B, Witthohn K, Zinke H and Lentzen H: Characterization of recombinant and plant-derived mistletoe lectin and their B-chains. Eur J Biochem 265: 788-797, 1999.

20. Eck J, Langer M, Möckel B, Baur A, Rothe M, Zinke H and Lentzen $\mathrm{H}$ : Cloning of the mistletoe lectin gene and characterization of the recombinant A-chain. Eur J Biochem 264: 775-784, 1999.

21. Zwierzina H, Bergmann L, Fiebig H, Aamdal S, Schöffski P, Witthohn $\mathrm{K}$ and Lentzen $\mathrm{H}$ : The preclinical and clinical activity of aviscumine: A potential anticancer drug. Eur J Cancer 47: 1450-1457, 2011.

22. Naumann U, Kügler S, Wolburg H, Wick W, Rascher G, Schulz JB, Conseiller E, Bähr M and Weller M: Chimeric tumor suppressor 1, a p53-derived chimeric tumor suppressor gene, kills p53 mutant and p53 wild-type glioma cells in synergy with irradiation and CD95 ligand. Cancer Res 61: 5833-5842, 2001.

23. Platten M, Wick W and Weller M: Malignant glioma biology: Role for TGF-beta in growth, motility, angiogenesis, and immune escape. Microsc Res Tech 52: 401-410, 2001.

24. Nakano A, Tani E, Miyazaki K, Yamamoto Y and Furuyama J: Matrix metalloproteinases and tissue inhibitors of metalloproteinases in human gliomas. J Neurosurg 83: 298-307, 1995.

25. Nikolai G, Friedl P, Werner M, Niggemann B and Zänker KS: Effect of a mistletoe extract (Iscador QuFrF) on viability and migratory behavior of human peripheral $\mathrm{CD}^{+}$and $\mathrm{CD}^{+} \mathrm{T}$ lymphocytes in three-dimensional collagen lattices. In Vitro Cell Dev Biol Anim 33: 710-716, 1997.

26. Gren A: Effects of Iscador preparations on the reactivity of mouse immune system. Neuro Endocrinol Lett 30: 530-534, 2009.

27. Kuttan $G$ and Kuttan R: Immunological mechanism of action of the tumor reducing peptide from mistletoe extract (NSC 635089) cellular proliferation. Cancer Lett 66: 123-130, 1992.

28. Braedel-Ruoff S: Immunomodulatory effects of Viscum album extracts on natural killer cells: Review of clinical trials. Forsch Komplement Med 17: 63-73, 2010.

29. Schink M, Tröger W, Dabidian A, Goyert A, Scheuerecker H, Meyer J, Fischer IU and Glaser F: Mistletoe extract reduces the surgical suppression of natural killer cell activity in cancer patients. a randomized phase III trial. Forsch Komplement Med 14: 9-17, 2007.

30. Antony S, Kuttan R and Kuttan G: Role of natural killer cells in iscador mediated inhibition of metastasis by adoptive immunotherapy. Immunol Invest 29: 219-231, 2000.

31. Thies A, Dautel P, Meyer A, Pfüller U and Schumacher U: Low-dose mistletoe lectin-I reduces melanoma growth and spread in a scid mouse xenograft model. Br J Cancer 98: 106-112, 2008.

32. Tröger W, Galun D, Reif M, Schumann A, Stanković N and Milićević M: Viscum album [L.] extract therapy in patients with locally advanced or metastatic pancreatic cancer: A randomised clinical trial on overall survival. Eur J Cancer 49: 3788-3797, 2013. 
33. Büssing A, Raak C and Ostermann T: Quality of life and related dimensions in cancer patients treated with mistletoe extract (iscador): A meta-analysis. Evid Based Complement Alternat Med 2012: 219402, 2012.

34. Ostermann T, Raak C and Büssing A: Survival of cancer patients treated with mistletoe extract (Iscador): A systematic literature review. BMC Cancer 9: 451, 2009.

35. Trefzer U, Gutzmer R, Wilhelm T, Schenck F, Kähler KC, Jacobi V, Witthohn K, Lentzen H and Mohr P: Treatment of unresectable stage IV metastatic melanoma with aviscumine after anti-neoplastic treatment failure: A phase II, multi-centre study. J Immunother Cancer 2: 27, 2014.

36. Naumann U, Maass P, Gleske AK, Aulwurm S, Weller M and Eisele G: Glioma gene therapy with soluble transforming growth factor-beta receptors II and III. Int J Oncol 33: 759-765, 2008.

37. Nakada M, Niska JA, Miyamori H, McDonough WS, Wu J, Sato $\mathrm{H}$ and Berens ME: The phosphorylation of EphB2 receptor regulates migration and invasion of human glioma cells. Cancer Res 64: 3179-3185, 2004

38. Wang SD, Rath P, Lal B, Richard JP, Li Y, Goodwin CR, Laterra J and Xia S: EphB2 receptor controls proliferation/migration dichotomy of glioblastoma by interacting with focal adhesion kinase. Oncogene 31: 5132-5143, 2012.

39. Huang Q, Zhang QB, Dong J, Wu YY, Shen YT, Zhao YD, Zhu YD, Diao Y, Wang AD and Lan Q: Glioma stem cells are more aggressive in recurrent tumors with malignant progression than in the primary tumor, and both can be maintained long-term in vitro. BMC Cancer 8: 304, 2008.

40. Zhang W, Men X and Lei P: Review on anti-tumor effect of triterpene acid compounds. J Cancer Res Ther 10 (Suppl 1): 14-19, 2014.

41. Kandaswami C, Lee LT, Lee PP, Hwang JJ, Ke FC, Huang YT and Lee MT: The antitumor activities of flavonoids. In Vivo 19 895-909, 2005

42. Gdynia G, Grund K, Eckert A, Böck BC, Funke B, MacherGoeppinger S, Sieber S, Herold-Mende C, Wiestler B, Wiestler OD, et al: Basal caspase activity promotes migration and invasiveness in glioblastoma cells. Mol Cancer Res 5: 1232-1240, 2007.

43. Liu W, Wei W, Winer D, Bamberger AM, Bamberger C, Wagener C, Ezzat $S$ and Asa SL: CEACAM1 impedes thyroid cancer growth but promotes invasiveness: A putative mechanism for early metastases. Oncogene 26: 2747-2758, 2007.

44. Ebrahimnejad A, Streichert T, Nollau P, Horst AK, Wagener C, Bamberger AM and Brümmer J: CEACAM1 enhances invasion and migration of melanocytic and melanoma cells. Am J Pathol 165: 1781-1787, 2004

45. Shekarabi M and Kennedy TE: The netrin-1 receptor DCC promotes filopodia formation and cell spreading by activating Cdc42 and Rac1. Mol Cell Neurosci 19: 1-17, 2002.

46. Nakada M, Kita D, Futami K, Yamashita J, Fujimoto N, Sato H and Okada Y: Roles of membrane type 1 matrix metalloproteinase and tissue inhibitor of metalloproteinases 2 in invasion and dissemination of human malignant glioma. J Neurosurg 94 464-473, 2001

47. Lam BD, Anthony EC and Hordijk PL: Analysis of nucleocytoplasmic shuttling of the proto-oncogene SET/I2PP2A Cytometry A 81: 81-89, 2012

48. Goertzen CG, Dragan M, Turley E, Babwah AV and Bhattacharya M: KISS1R signaling promotes invadopodia formation in human breast cancer cell via $\beta$-arrestin2/ERK. Cell Signal 28: 165-176, 2016

49. Wu F, Li JQ, Miki H, Nishioka M, Fujita J, Ohmori M, Imaida K and Kuriyama S: p107 Expression in colorectal tumours rises during carcinogenesis and falls during invasion. Eur J Cancer 38 : 1838-1848, 2002.

50. Mei P, Bai J, Shi M, Liu Q, Li Z, Fan Y and Zheng J: BRMS1 suppresses glioma progression by regulating invasion, migration and adhesion of glioma cells. PLoS One 9: e98544, 2014.

51. Sooman L, Freyhult E, Jaiswal A, Navani S, Edqvist PH, Pontén F, Tchougounova E, Smits A, Elsir T, Gullbo J, et al: FGF2 as a potential prognostic biomarker for proneural glioma patients. Acta Oncol 54: 385-394, 2015.

52. Chen D, Persson A, Sun Y, Salford LG, Nord DG, Englund E, Jiang $\mathrm{T}$ and Fan X: Better prognosis of patients with glioma expressing FGF2-dependent PDGFRA irrespective of morphological diagnosis. PLoS One 8: e61556, 2013.

53. Boissan M, Poupon MF and Lacombe ML: NM 23 and metastasis suppressor genes: Update. Med Sci (Paris) 23: 1115-1123, 2007 (In French).
54. McDermott WG, Boissan M, Lacombe ML, Steeg PS and Horak CE: Nm23-H1 homologs suppress tumor cell motility and anchorage independent growth. Clin Exp Metastasis 25: 131-138, 2008.

55. Chou RH, Wen HC, Liang WG, Lin SC, Yuan HW, Wu CW and Chang WS: Suppression of the invasion and migration of cancer cells by SERPINB family genes and their derived peptides. Oncol Rep 27: 238-245, 2012 .

56. Xu L, Liu H, Yu J, Wang Z, Zhu Q, Li Z, Zhong Q, Zhang S, $\mathrm{Qu} \mathrm{M}$ and Lan Q: Methylation-induced silencing of maspin contributes to the proliferation of human glioma cells. Oncol Rep 36: 57-64, 2016.

57. Lam S, Wiercinska E, Teunisse AF, Lodder K, ten Dijke P and Jochemsen AG: Wild-type $\mathrm{p} 53$ inhibits pro-invasive properties of TGF- $\beta 3$ in breast cancer, in part through regulation of EPHB2, a new TGF- $\beta$ target gene. Breast Cancer Res Treat 148: 7-18, 2014.

58. Wang M, Wang T, Liu S, Yoshida D and Teramoto A: The expression of matrix metalloproteinase-2 and -9 in human gliomas of different pathological grades. Brain Tumor Pathol 20: 65-72, 2003.

59. Wang L, Yuan J, Tu Y, Mao X, He S, Fu G, Zong J and Zhang Y: Co-expression of MMP-14 and MMP-19 predicts poor survival in human glioma. Clin Transl Oncol 15: 139-145, 2013.

60. Ulasov I, Yi R, Guo D, Sarvaiya P and Cobbs C: The emerging role of MMP14 in brain tumorigenesis and future therapeutics. Biochim Biophys Acta 1846: 113-120, 2014.

61. Shastry AH, Thota B, Arimappamagan A and Santosh V: P53 stratification reveals the prognostic utility of matrix metalloproteinase-9 protein expression in glioblastoma. Neurol India 63: 399-404, 2015

62. Asuthkar S, Velpula KK, Chetty C, Gorantla B and Rao JS: Epigenetic regulation of miRNA-211 by MMP-9 governs glioma cell apoptosis, chemosensitivity and radiosensitivity. Oncotarget 3: 1439-1454, 2012.

63. Hofer MD, Menke A, Genze F, Gierschik P and Giehl K: Expression of MTA1 promotes motility and invasiveness of PANC-1 pancreatic carcinoma cells. Br J Cancer 90: 455-462, 2004.

64. Cheng CY, Chou YE, Ko CP, Yang SF, Hsieh SC, Lin CL, Hsieh YH and Chen KC: Metastasis tumor-associated protein-2 knockdown suppresses the proliferation and invasion of human glioma cells in vitro and in vivo. J Neurooncol 120: 273-281, 2014.

65. ten Klooster JP, Leeuwen I, Scheres N, Anthony EC and Hordijk PL: Racl-induced cell migration requires membrane recruitment of the nuclear oncogene SET. EMBO J 26: 336-345, 2007.

66. Li J, Yang XF, Ren XH, Meng XJ, Huang HY, Zhao QH, Yuan JH, Hong WX, Xia B, Huang XF, et al: Stable SET knockdown in breast cell carcinoma inhibits cell migration and invasion. Biochem Biophys Res Commun 453: 7-12, 2014

67. Gomez DE, Alonso DF, Yoshiji H and Thorgeirsson UP: Tissue inhibitors of metalloproteinases: Structure, regulation and biological functions. Eur J Cell Biol 74: 111-122, 1997.

68. Lu KV,Jong KA, Rajasekaran AK, Cloughesy TF and Mischel PS: Upregulation of tissue inhibitor of metalloproteinases (TIMP)-2 promotes matrix metalloproteinase (MMP)-2 activation and cell invasion in a human glioblastoma cell line. Lab Invest 84: 8-20, 2004.

69. Mikheeva SA, Mikheev AM, Petit A, Beyer R, Oxford RG, Khorasani L, Maxwell JP, Glackin CA, Wakimoto $\mathrm{H}$, González-Herrero I, et al: TWIST1 promotes invasion through mesenchymal change in human glioblastoma. Mol Cancer 9: 194, 2010.

70. Elias MC, Tozer KR, Silber JR, Mikheeva S, Deng M, Morrison RS, Manning TC, Silbergeld DL, Glackin CA, Reh TA, et al: TWIST is expressed in human gliomas and promotes invasion. Neoplasia 7: 824-837, 2005.

71. Madan E, Dikshit B, Gowda SH, Srivastava C, Sarkar C, Chattopadhyay P, Sinha S and Chosdol K: FAT1 is a novel upstream regulator of HIF1 $\alpha$ and invasion of high grade glioma. Int J Cancer 139: 2570-2582, 2016.

72. Lu KV, Chang JP, Parachoniak CA, Pandika MM, Aghi MK, Meyronet D, Isachenko N, Fouse SD, Phillips JJ, Cheresh DA, et al: VEGF inhibits tumor cell invasion and mesenchymal transition through a MET/VEGFR2 complex. Cancer Cell 22: 21-35, 2012.

73. Kast RE: The role of interleukin-18 in glioblastoma pathology implies therapeutic potential of two old drugs-disulfiram and ritonavir. Chin J Cancer 34: 161-165, 2015. 
74. Fathima Hurmath K, Ramaswamy P and Nandakumar DN IL-1 $\beta$ microenvironment promotes proliferation, migration, and invasion of human glioma cells. Cell Biol Int 38: 1415-1422, 2014.

75. Lyu SY and Park WB: Effects of Korean mistletoe lectin (Viscum album coloratum) on proliferation and cytokine expression in human peripheral blood mononuclear cells and T-lymphocytes. Arch Pharm Res 30: 1252-1264, 2007.

76. Sunaga N, Imai H, Shimizu K, Shames DS, Kakegawa S, Girard L, Sato M, Kaira K, Ishizuka T, Gazdar AF, et al: Oncogenic KRASinduced interleukin-8 overexpression promotes cell growth and migration and contributes to aggressive phenotypes of non-small cell lung cancer. Int J Cancer 130: 1733-1744, 2012.

77. Pullen NA, Anand M, Cooper PS and Fillmore HL: Matrix metalloproteinase-1 expression enhances tumorigenicity as well as tumor-related angiogenesis and is inversely associated with TIMP-4 expression in a model of glioblastoma. J Neurooncol 106: 461-471, 2012.

78. Anand M, Van Meter TE and Fillmore HL: Epidermal growth factor induces matrix metalloproteinase-1 (MMP-1) expression and invasion in glioma cell lines via the MAPK pathway. J Neurooncol 104: 679-687, 2011.
79. Dhruv HD, McDonough Winslow WS, Armstrong B, Tuncali S, Eschbacher J, Kislin K, Loftus JC, Tran NL and Berens ME: Reciprocal activation of transcription factors underlies the dichotomy between proliferation and invasion of glioma cells. PLoS One 8: e72134, 2013.

80. Jung S, Paek YW, Moon KS, Wee SC, Ryu HH, Jeong YI, Sun HS, Jin YH, Kim KK and Ahn KY: Expression of Nm23 in gliomas and its effect on migration and invasion in vitro. Anticancer Res 26: 249-258, 2006

81. Xu K, Wang L and Shu HK: COX-2 overexpression increases malignant potential of human glioma cells through Id1. Oncotarget 5: 1241-1252, 2014.

82. Belot N, Pochet R, Heizmann CW, Kiss R and Decaestecker C: Extracellular S100A4 stimulates the migration rate of astrocytic tumor cells by modifying the organization of their actin cytoskeleton. Biochim Biophys Acta 1600: 74-83, 2002.

83. Klein RM, Bernstein D, Higgins SP, Higgins CE and Higgins PJ: SERPINE1 expression discriminates site-specific metastasis in human melanoma. Exp Dermatol 21: 551-554, 2012. 